\title{
AN EVALUATION WITH WINDOW ANALYSIS TO DETERMINE THE ENVIRONMENTAL EFFICIENCIES OF THE COUNTRIES THAT POLLUTE THE WORLD
}

\author{
ihsan ALP1, Mihraç KÜPELi
}

\begin{abstract}
As it is known, The Kyoto Protocol is an international agreement aims to reduce global warming and manmade greenhouse gas emissions. Approximately 160 countries entered into framework of the Kyoto Protocol and our world is polluted by about 50 countries mostly. The purpose of this study is to investigate values and the trends of performances of environmental/greenhouse gas emissions of these 50 most polluted countries in period of 2005-2015. At the same time, it is examined that the trend of the performance of Turkey in the concerned years. Window Analysis (WA) is a DEA and operational research (OR) based technique. DEA captures a moment photograph, each application is a cross-sectional analysis of data. In some applications, observations for DMUs are available over multiple time periods, so to perform an analysis where interest focuses on changes over time is important. WA gives us trend of changes of performance over time, and also details of the stability of performance.
\end{abstract}

Keywords: Data envelopment analysis, window analysis, nations, greenhouse gas emissions, performance

JEL Classification: $\mathrm{C} 6, \mathrm{Q} 3, \mathrm{Q} 4$

\section{DÜNYAYI KIRLETEN ÜLKELERIN ÇEVRESEL ETKINLIKLERINI BELIRLEMEK IÇiN PENCERE ANALIZi iLE BiR DEĞERLENDIRME}

\section{Öz}

Bilindiği gibi, Kyoto Protokolü küresel ısınmayı ve insan yapımı sera gazı salımını azaltmayı amaçlayan uluslararası bir anlaşmadır. Kyoto Protokolü çerçevesine yaklaşık 160 ülke girmektedir ve dünya çoğunlukla 50 ülke tarafından kirletilmektedir. Bu çalışmanın amacı, 2005-2015 döneminde ençok kirleten 50 ülkenin çevre ve sera gazı emisyonlarının değerlerini ve eğilimlerini araştırmaktır. Aynı zamanda Türkiye'nin bu zaman dilimindeki performans eğilimini ve kararlılığını incelemektir. Window Analizi bir tür Veri Zarflama Analizi'dir ve yöneylem araştırması tabanlı bir tekniktir. Veri Zarflama Analizinde veriler kesitsel olarak analiz edilirler. Bazı uygulamalarda ise karar verme birimleri için gözlemler çoklu zaman dilimlerinde mevcuttur. Bu nedenle farklı zaman içindeki değişimlere odaklı bir analiz yapmak önemlidir. Window analizi zaman içindeki performans değişimlerinin eğilimini ve performans kararlığının detaylarını sunmaktadır.

Anahtar Kelimeler: Veri zarflama analizi, window analizi, sera gazı emisyonu, performans JEL Sınıflandırması: C6,Q3,Q4

\footnotetext{
1 Prof. Dr., Gazi Üniversitesi, Fen Fakültesi, İstatistik Bölümü, ihsanalp@gazi.edu.tr

${ }^{2}$ Araş. Gör., Gazi Üniversitesi, Fen Fakültesi, istatistik Bölümü, mihrac.kupeli@gazi.edu.tr
} 


\section{Introduction}

Recently, global warming and climate change have emerged as two main issues in the scientific and political agenda. It is widely accepted that these environmental problems represent a serious threat for the life conditions of hundreds of million people. The risk of climate change due to emissions of greenhouse gas (GHG) from fossil fuels is considered to be the main environmental threat (Demirbas, 2003). The accelerating use of fossil fuels since the industrial revolution and rapid destruction of forests have led to a significant increase in the anthropogenic GHGs (Tunc et al., 2007). The Kyoto Protocol can be cited as the most important agreement which seeks to limit the countries' emissions within a time horizon (Tunc et al., 2007). The Kyoto marks an important turning point in efforts to promote the use of renewable energy as a key strategy for reducing GHG emissions worldwide. Turkey has signed the Kyoto Protocol on February 17th, 2009. To reach the level envisaged in the protocol, the status of GHG emissions should be reviewed and strategic plans must be made within the context of the compliance with protocol. Turkey is obliged to fulfill the liabilities of GHG emissions as a candidate country of the European Union (EU)(Sözen and Alp, 2009).

Environmental efficiency assessment is one of the most important ways to quantitatively evaluate the performance of and interaction between economy and environment. Many efficiency analysis techniques have been proposed to calculate Environmental Efficiency (EE). Based on the production possibility frontier theory, these methods can be mainly divided into two types: parametric and nonparametric. The representatives of the parametric and nonparametric methods are stochastic frontier analysis (SFA) (Aigner et al., 1977; Meeusen and Broeck, 1977) and data envelopment analysis (DEA) (Charnes et al., 1978), respectively. SFA employed regression analysis to estimate the relationship between inputs and outputs. The efficiency of peer decision making units (DMUs) is decomposed into two parts: a stochastic error term and a systematic inefficiency term. In contrast to SFA, DEA method does not need to specify the functional relations between inputs and outputs. DEA is a nonparametric approach for measuring the relative efficiency of DMUs that have multiple inputs and outputs. Compared with SFA, DEA is easier to use in various circumstances with multiple variables (Lee et all, 2014; Reinhard et all, 2000; Zofío and Prieto, 2001; Mandal and Madheswaran 2010; Agrell and Bogetoft, 2005).

Window Analysis (WA) is a DEA and operational research (OR) based technique. DEA captures a moment photograph, each application is a cross-sectional analysis of data. In some applications, observations for DMUs are available over multiple time periods, so to perform an analysis where interest focuses on changes over time is important. WA gives us trend of changes of performance over time, and also details of the stability of performance.

\section{Literature Rewiev}

Data envelopment analysis (DEA) has gained great popularity in energy and emissions modeling during the past decades. Most research articles studied on DEA are on the linkages among CO2 emissions, energy consumption and gross domestic product growth. (Zhou et al., 2008; Honma and $\mathrm{Hu}, 2008$; Honma and Hu, 2009; Ramakrishnan, 2006; Lozano and Gutierrez, 2008).

Numerous literature have studied environmental efficiency using the DEA method. Table 1. listed some of the existing studies on environmental efficiency. The majority of them focused on the country-level or provincial-level EEs, while few of them paid much attention to the city-level EE analysis. 
Table 1: Literature Rewiev

\begin{tabular}{|c|c|c|c|c|}
\hline Researcher & Method & Study area & Input & Output \\
\hline $\begin{array}{l}\text { Ramakrishnan } \\
2006\end{array}$ & DEA & 1988-2001 World & $\begin{array}{l}\text { World GDP, energy } \\
\text { consumption }\end{array}$ & $\mathrm{CO} 2$ \\
\hline Zhou et al. 2007 & $\begin{array}{l}\text { Non-radial } \\
\text { Malmquist }\end{array}$ & $\begin{array}{l}26 \text { OECD countries, } \\
1995-1997\end{array}$ & Labor & $\begin{array}{l}\text { GDP, CO2, SOx, } \\
\text { NOx, CO }\end{array}$ \\
\hline $\begin{array}{l}\text { Chien and } \\
\text { Hu } 2007\end{array}$ & DEA & $\begin{array}{l}45 \text { countries, } 2001 \\
\text { and } 2002\end{array}$ & $\begin{array}{l}\text { Labor, capital, } \\
\text { energy }\end{array}$ & GDP \\
\hline $\begin{array}{l}\text { Lozano and } \\
\text { Gutierrez } 2008\end{array}$ & DEA & $\begin{array}{l}26 \text { Countries from } \\
\text { World }\end{array}$ & $\begin{array}{l}\text { Population and } \\
\text { GDP }\end{array}$ & Greenhouse Gases \\
\hline $\begin{array}{l}\text { Honma and } \mathrm{Hu} \\
2008\end{array}$ & Malmquist & $\begin{array}{l}47 \text { prefectures of } \\
\text { Japan }\end{array}$ & $\begin{array}{l}\text { Real GDP, capital, } \\
\text { energy, Oil, Gas, } \\
\text { Coal, Coke }\end{array}$ & Total Income \\
\hline $\begin{array}{l}\text { Honma and } \mathrm{Hu} \\
2009\end{array}$ & DEA & $\begin{array}{l}17 \text { sectors in } \\
\text { Japanese economy }\end{array}$ & $\begin{array}{l}\text { Labor, capital, } \\
\text { energy }\end{array}$ & $\begin{array}{l}\text { Value added in } \\
\text { each sector }\end{array}$ \\
\hline $\begin{array}{l}\text { Sözen and Alp, } \\
2009\end{array}$ & DEA & $\begin{array}{l}\text { EU countries and } \\
\text { Turkey }\end{array}$ & $\begin{array}{l}\text { Primary energy, } \\
\text { energy } \\
\text { consumption by } \\
\text { sectors }\end{array}$ & $\begin{array}{l}\mathrm{GHG}, \mathrm{SO} 2, \mathrm{NO}, \\
\mathrm{CO} 2 \text { and others }\end{array}$ \\
\hline $\begin{array}{l}\text { Halkos and } \\
\text { Tzeremes } 2013\end{array}$ & Bootstrapped DEA & $\begin{array}{l}110 \quad \text { countries, } \\
2007\end{array}$ & Labor, capital & GDP, $\mathrm{CO} 2$ \\
\hline Li et al. 2013 & DEA, Tobit & Beijing, 2005-2009 & $\begin{array}{l}\text { Labor, } \\
\text { energy }\end{array}$ & $\begin{array}{l}\text { GDP, waste water, } \\
\text { solid waste }\end{array}$ \\
\hline $\begin{array}{l}\text { Wang } \\
\text { et al. } 2013\end{array}$ & $\begin{array}{l}\text { DEA window } \\
\text { analysis }\end{array}$ & $\begin{array}{l}29 \text { provinces in } \\
\text { China, } 2000-2008\end{array}$ & $\begin{array}{l}\text { Labor, } \\
\text { energy }\end{array}$ & $\mathrm{GDP}, \mathrm{CO} 2, \mathrm{SO} 2$ \\
\hline Zhou et al. 2013 & Entropy SBM DEA & $\begin{array}{l}30 \text { provinces in } \\
\text { China, } 2005-2010\end{array}$ & $\begin{array}{l}\text { Labor, } \\
\text { energy }\end{array}$ & $\begin{array}{l}\text { Power capacity, } \\
\mathrm{SO} 2, \mathrm{NOx}, \mathrm{CO} 2\end{array}$ \\
\hline $\begin{array}{l}\text { Yang and Wang } \\
2013\end{array}$ & DEA & $\begin{array}{l}29 \text { provinces in } \\
\text { China, } 2000-2007\end{array}$ & $\begin{array}{l}\text { Labor, } \\
\text { energy }\end{array}$ & $\mathrm{GDP}, \mathrm{CO} 2$ \\
\hline Changet al.2013 & SBM DEA & $\begin{array}{l}30 \text { provinces in } \\
\text { China, } 2009\end{array}$ & $\begin{array}{l}\text { Labor, } \\
\text { energy }\end{array}$ & $\begin{array}{l}\text { value-added of } \\
\text { transportation } \\
\text { sector, } \mathrm{CO} 2\end{array}$ \\
\hline Song et al. 2013 & SBM DEA, Tobit & $\begin{array}{l}29 \text { provinces in } \\
\text { China, 1998-2009 }\end{array}$ & $\begin{array}{l}\text { Labor, } \\
\text { energy }\end{array}$ & $\begin{array}{l}\text { GDP, waste water, } \\
\text { solid waste, waste } \\
\text { gas }\end{array}$ \\
\hline $\begin{array}{l}\text { Wang } \\
\text { et al. } 2013\end{array}$ & Non-radial DDF & $\begin{array}{l}28 \text { provinces in } \\
\text { China, } 2005-2010\end{array}$ & $\begin{array}{l}\text { Labor, } \\
\text { energy }\end{array}$ & GDP, $\mathrm{CO} 2$ \\
\hline $\begin{array}{l}\text { Wang et al. } \\
2013\end{array}$ & Meta-frontier, DEA & $\begin{array}{l}211 \text { cities in China, } \\
2008\end{array}$ & $\begin{array}{l}\text { Labor, } \\
\text { energy }\end{array}$ & GDP, SO2 \\
\hline Zhou et al. 2013 & Weighted SBM & $\begin{array}{l}27 \text { industrial } \\
\text { sectors in China }\end{array}$ & $\begin{array}{l}\text { Industry } \\
\text { investment, } \\
\text { employees, coal, } \\
\text { oil, gas }\end{array}$ & $\begin{array}{l}\text { industry } \\
\text { production, solid } \\
\text { wastes, waste gas, } \\
\text { waste water }\end{array}$ \\
\hline $\begin{array}{l}\text { Song and Guan } \\
2014\end{array}$ & SESBM, Malmquist & $\begin{array}{l}\text { Wanjiang } \\
\text { demonstration } \\
\text { area, } 2010 \text { and } \\
2011\end{array}$ & $\begin{array}{l}\text { Population, } \\
\text { capital, energy }\end{array}$ & $\begin{array}{l}\text { GDP, industrial } \\
\text { SO2 }\end{array}$ \\
\hline Woo et al. 2015 & DEA, Malmquist & $\begin{array}{l}31 \text { OECD countries, } \\
2004-2011\end{array}$ & $\begin{array}{l}\text { Labor, } \\
\text { energy }\end{array}$ & GDP, $\mathrm{CO} 2$ \\
\hline
\end{tabular}

The majority of sduies focused on the country-level or provincial-level EEs, while few of them paid much attention to the city-level EE analysis. Understanding city-level EEs can help us gain a better understanding of regional imbalance, which is beneficial for making decisions towards regional development strategy, especially for economic zones. There are also some researchers focusing on city-level EE assessment. 


\section{Data, Variables and Model}

Approximately 160 countries entered into framework of the Kyoto Protocol and our world is polluted mostly by about 50 countries. The purpose of study is to investigate values and the trends of performances of environmental/greenhouse gas emissions of these 50 most polluted countries in period of 2005-2015. At the same time, it is examined that the trend of the performance of Turkey in the concerned years. Data are taken from Wold Bank statistics site.

50 countries which most polluted the World are the following: Argentina, Australia, Austria, Belgium, Brazil, Bulgaria, Canada, Chile, China, Czech, Denmark, Egypt, Finland, France, Germany, Greece, Hungary, India, Indenosia, Iran, Ireland, Israel, Italy, Japan, Kazakhstan, Korea, Malaysia, Mexico, Morocco, Netherlands, New Zealand, Norway, Pakistan, Peru, Philippines, Poland, Portugal, Romania, Russia, Saudi Arabia, South Africa, Spain, Sweden, Thailand, Turkey, Ukrania, UK, US, Vietnam, Venezuella.

In this study, when calculating dynamic performance changes of 50 countries the following variables that generally used in literature were selected. These are: Economic (labour and capital), environmental (freshwater) and energy inputs with a desirable output (GDP) and three undesirable outputs greenhouse gases ( $\mathrm{CO} 2$, methane and nitrous oxide emissions etc.). The directions of undesired variables have been changed in a suitable way.

Table 2: Summary Statistics of Variables and Model's Inputs and Outputs

\begin{tabular}{cccccc}
\hline Variables & $\begin{array}{c}\text { Input/Output in } \\
\text { Model }\end{array}$ & Mean & Std. Deviation & Minimum & Maximum \\
Labor total & $\mathrm{I}$ & 52763853,36 & 131503911,71 & 2184332 & 806498521 \\
Freshwater & $\mathrm{I}$ & 67,24 & 143,20 &, 65 & 761,00 \\
Capital & $\mathrm{I}$ & 19761,28 & 17704,22 & 813,70 & 67223,02 \\
Energy & $\mathrm{I}$ & 3012,82 & 1787,35 & 457,13 & 7247,23 \\
$\mathrm{CO}_{2}$ & $\mathrm{O}$ & 6423,23 & 969,76 & 99,20 & 6713,00 \\
Methane & $\mathrm{O}$ & 1726,48 & 274,30 & 99,70 & 1848,58 \\
$\mathrm{NO}_{2}$ & $\mathrm{O}$ & 641,03 & 97,15 & 99,83 & 685,24 \\
GDP & $\mathrm{O}$ & 28574,00 & 15591,72 & 5041,71 & 61471,57 \\
\hline
\end{tabular}

The gases that hold the heat in the atmosphere are called the greenhouse gas. These are:

Carbon dioxide ( $\mathrm{CO} 2$ ): is the primary greenhouse gas emitted through human activities. While $\mathrm{CO} 2$ emissions come from a variety of natural sources, human-related emissions are responsible for the increase that has occurred in the atmosphere since the industrial revolution. Carbon dioxide enters the atmosphere through burning fossil fuels (coal, natural gas, and oil) for energy and transportation, Although certain industrial processes and land-use changes also emit CO2.), Solid waste, trees and wood products, and also as a result of certain chemical reactions (e.g., manufacture of cement). Changes in $\mathrm{CO} 2$ emissions from fossil fuel combustion are influenced by many long-term and short-term factors, including population growth, economic growth, changing energy prices, new technologies, changing behavior, and seasonal temperatures.

And overall growth in emissions from electricity generation, and increased demand for travel and transportation.

Methane ( $\mathrm{CH} 4)$ : Methane is emitted during the production and transport of coal, natural gas, and oil. Methane emissions also result from livestock and other agricultural practices and by the decay of organic waste in municipal solid waste landfills.

Agricultural activities, waste management, energy use, and biomass burning all contribute to $\mathrm{CH} 4$ emissions.

Nitrous oxide (N2O): Nitrous oxide is emitted during agricultural and industrial activities, as well as during combustion of fossil fuels and solid waste. 


\subsection{Trends in Global Emissions}

Global carbon emissions from fossil fuels have significantly increased since 1900. Since 1970, CO2 emissions have increased by about $90 \%$.

Graph 1: Global Carbon Emissions from Fossil Fuels, 1900-2014

\section{Global Carbon Emissions from Fossil Fuels, 1900-2014}

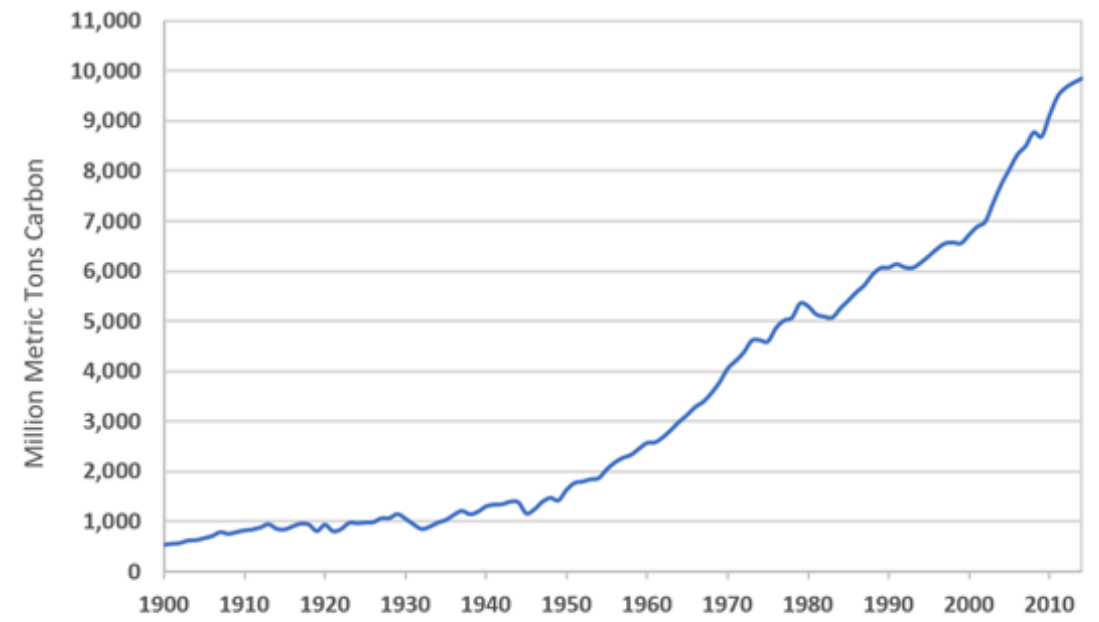

Source: Boden, T.A., Marland, G., and Andres, R.J. (2017). Global, Regional, and National Fossil-Fuel CO2Emissions. Carbon Dioxide Information Analysis Center, Oak Ridge National Laboratory, U.S. Department of Energy, Oak Ridge, Tenn., U.S.A. doi 10.3334/CDIAC/00001_V2017

\subsection{Global Emissions by Economic Sector}

Global greenhouse gas emissions can also be broken down by the economic activities that lead to their production.

\section{Graph 2:Greenhouse Gas Emissions by Sectors}

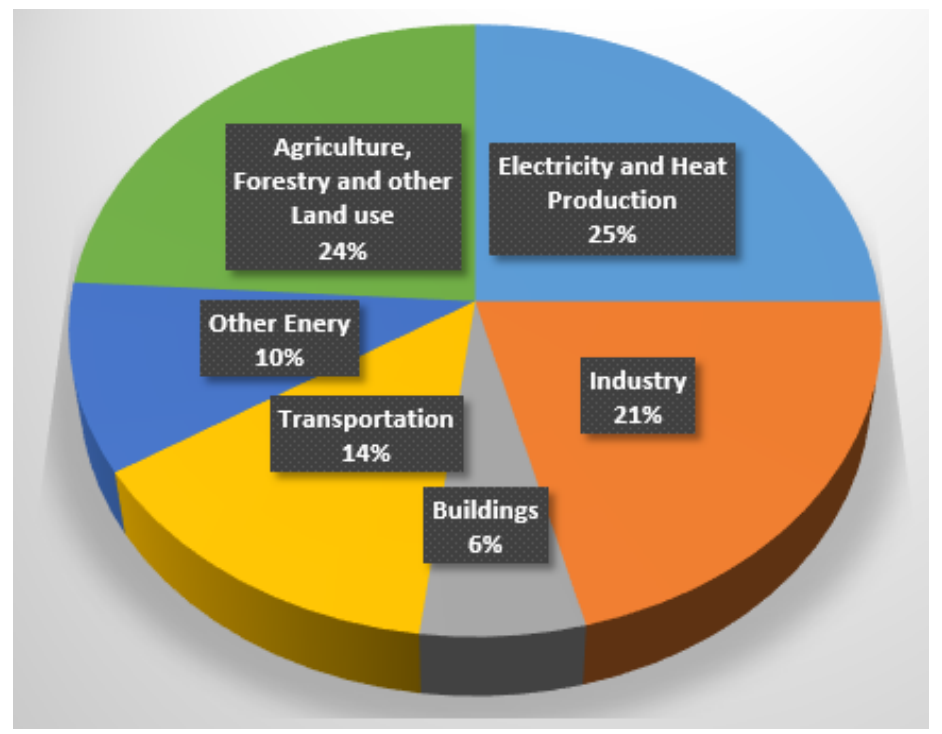


Source: IPCC (2014) Exit based on global emissions from 2010. Details about the sources included in these estimates can be found in the Contribution of Working Group III to the Fifth Assessment Report of the Intergovernmental Panel on Climate Change.

- Electricity and Heat Production (25\% of 2010 global greenhouse gas emissions): The burning of coal, natural gas, and oil for electricity and heat is the largest single source of global greenhouse gas emissions.

-Industry (21\% of 2010 global greenhouse gas emissions): Greenhouse gas emissions from industry primarily involve fossil fuels burned on site at facilities for energy. This sector also includes emissions from chemical, metallurgical, and mineral transformation processes not associated with energy consumption and emissions from waste management activities. (Note: Emissions from industrial electricity use are excluded and are instead covered in the Electricity and Heat Production sector.)

-Agriculture, Forestry, and Other Land Use (24\% of 2010 global greenhouse gas emissions): Greenhouse gas emissions from this sector come mostly from agriculture(cultivation of crops and livestock) and deforestation. This estimate does not include the $\mathrm{CO} 2$ that ecosystems remove from the atmosphere by sequestering carbon in biomass, dead organic matter, and soils, which offset approximately $20 \%$ of emissions from this sector.

-Transportation (14\% of 2010 global greenhouse gas emissions): Greenhouse gas emissions from this sector primarily involve fossil fuels burned for road, rail, air, and marine transportation. Almost all (95\%) of the world's transportation energy comes from petroleum-based fuels, largely gasoline and diesel.

-Buildings (6\% of 2010 global greenhouse gas emissions): Greenhouse gas emissions from this sector arise from onsite energy generation and burning fuels for heat in buildings or cooking in homes. (Note: Emissions from electricity use in buildings are excluded and are instead covered in the Electricity and Heat Production sector.)

- Other Energy (10\% of 2010 global greenhouse gas emissions): This source of greenhouse gas emissions refers to all emissions from the Energy sector which are not directly associated with electricity or heat production, such as fuel extraction, refining, processing, and transportation.

\subsection{Emissions by Country}

In 2014, the top carbon dioxide (CO2) emitters were China, the United States, the European Union, India, the Russian Federation, and Japan.

These data include $\mathrm{CO} 2$ emissions from fossil fuel combustion, as well as cement manufacturing and gas flaring. Together, these sources represent a large proportion of total global $\mathrm{CO} 2$ emissions.

Emissions and sinks related to changes in land use are not included in these estimates. However, changes in land use can be important: estimates indicate that net global greenhouse gas emissions from agriculture, forestry, and other land use were over 8 billion metric tons of $\mathrm{CO} 2$ equivalent,or about $24 \%$ of total global greenhouse gas emissions(www.epa.gov,https://www.epa.gov/ghgemissions/global-greenhouse-gas-emissionsdata references 1-2-3). 


\section{Graph 3: Emissions by Country}

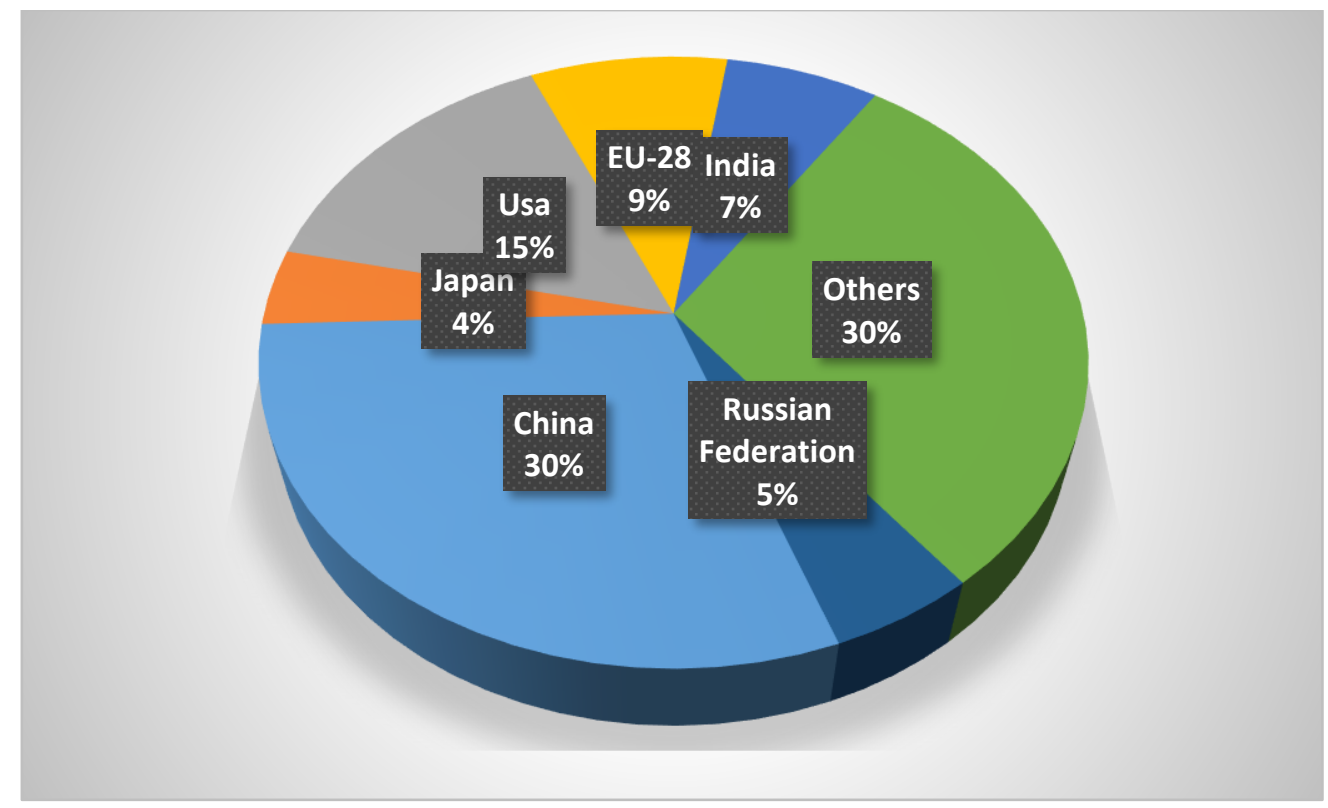

Source: Boden, T.A., Marland, G., and Andres, R.J. (2017). Global, Regional, and National FossilFuel CO2Emissions. Carbon Dioxide Information Analysis Center, Oak Ridge National Laboratory, U.S. Department of Energy, Oak Ridge, Tenn., U.S.A. doi 10.3334/CDIAC/00001_

\section{Model}

\section{1. Data Envelopment Analysis}

A nonparametric technique known as Data Envelopment Analysis (DEA), developed by Charnes, Cooper, and Rhodes (CCR, Charnes et al., 1978 ) and based on Farrell's efficiency measurement opinion. While Farrell's original idea is concerned with one input and one output, but the DEA method of Charnes, Cooper, and Rhodes can related the case where organizations ( i.e. decision making units, (DMUs) ) use multiple inputs to produce multiple outputs simultaneously. A DMU is defined as the concrete or intangible systems responsible for transforming inputs into outputs, and whose performance is evaluated. Examples of such units to which DEA has been applied are as follows: nations, banks, hospitals, schools, airports, tax offices, libraries, universities or their departments and also environment and energy organizations (Emrouznejad et al., 2008; Ray, 2004; Cook and Seiford, 2009; Sözen and Alp, 2009; Alp and Sözen, 2011). Note that one advantage of DEA is that it can be applied to not-for-profit organizations participating in public programs.

DEA is a powerful new methodology for organizing and analyzing data and for identifying best practice frontiers. The basic idea of DEA is to identify the most efficient decision making unit/s among all DMUs. The most efficient DMU is called a Pareto-optimal unit and is considered the standard for comparison for all other DMUs. DEA uses linear programming technique to determine the efficiency frontier. The points, which lie on the frontier comprises the efficient companies DMUs and the inefficient companies DMUs lie below the frontier.

The aim of DEA is to quantify the distance to the efficient frontier for every DMU. The measure of performance is expressed in the form of efficiency score. After the evaluation of the relative efficiency of the present set of units, DEA shows how inputs and outputs have to be changed in order to maximize the efficiency of the target DMU. DEA suggest the benchmark for each inefficient DMU at the level of its individual mix of inputs and outputs.

\section{Uluslararası Iktisadi ve idari incelemeler Dergisi}


DEA models can be classified by two criteria: Type of scale effects and model orientation. The first criterion determines the assumptions concerning the scale effects accepted in the model ( constant returns to scale (CRS), or variable returns to scale (VRS)). The model orientation approach indicates whether the objective is the minimisation of input(s), such as the cost of production, or the maximisation of a particular output, such as profit. In this study we used the input-oriented CCR (CRS) model. Using these model, the efficiency score is determined by holding output constant and assessing to what extent inputs would have to be improved (decresad) in order for a DMU to be considered efficient.

The dual form of CCR (CRS) input-oriented model (1) is as follows:

$$
\begin{aligned}
& \min \quad h_{o}=\phi-\varepsilon \cdot \sum_{r=1}^{s} S_{r}^{+}-\varepsilon \cdot \sum_{i=1}^{m} S_{i}^{-} \\
& \text {Subject to } \\
& \phi \cdot y_{r o}-\sum_{j=1}^{n} \lambda_{j} x_{r j}-S_{r}^{+}=0 \\
& \sum_{j=1}^{n} \lambda_{j} y_{i j}-S_{i}^{-}=y_{i o} \\
& \lambda_{j,} S_{i}^{-}, S_{r}^{+} \geq 0 \\
& j=1, \ldots, n, i=1, \ldots, m, \quad r=1, \ldots, s
\end{aligned}
$$

Where the subscript o represents the DMU being assessed and efficiency score of DMUo. xij, yrj denotes the input $i$ and output $r$ of $D M U_{i}$, respectively. $\varepsilon$ is an arbitrary small "non-Arcimedian" number. are the slacks in the ith and the $r$ th input and output and $n, m$ and $s$ are the number of DMUs, inputs, and outputs respectively.

From the dual CCR model, input augmentation is accomplished through the variable. If is less than 1.0 (or 100 ) and / or the slacks are not zero, then the DMU under investigation is inefficient, To improve and shift the DMU towards onto the frontier, a proportional decrease of for all inputs is required, followed poteantially, by an adjustment of individual slacks.

\subsection{Window Analysis}

In many DEA applications cross-sectional data were used. Each DMU unit is observed only one time in the studies. If multi-period data exist, in combination with the individual efficiency of each DMU, it is often important to perform a panel data analysis where the focus is on changes in efficiency over time. However, for this purpose, one approach to performing longitudinal analysis is to compare cross-sectional performance series across the number of time periods in the study. This approach introduces variability into the analysis because it treats the performance of a DMU in each time period as independent from its performance in the previous period. Also, with this approach it is not feasible to ascertain trends in performance or to observe persistence of efficiency or inefficiency, where the window analysis approach corrects some of these problems. In such a setting, it is possible to perform DEA over time using a moving average analogue (of time series), where a DMU in each different time period is treated as a distinct DMU. Specifically, a DMU's performance in a particular period is contrasted with its performance in other periods in addition to the performance of the other DMUs (Cooper et al.). While ordinary DEA results table can be named as "static table", window analysis results table is regarded as "dynamic table".

\section{Application}

In this study Window Analysis solutions of most polluted coutries were obtained by Efficiency Measurement System software (EMS 1.3.0 version from Dortmund University). The average, 
standard deviation, and range statistics of each country's performance scores were calculated. And according to these statistics ranked in decreasing order. Results are at Table 3.

Table 3: Distribution Of Performance Scores and Other Statistics of Most Polluted Countries of World

\begin{tabular}{|c|c|c|c|c|c|c|}
\hline DMU & Mean & SDeviation & Max & Min & Range & Rank \\
\hline China & $25,59 \%$ & $1,04 \%$ & $28,15 \%$ & $24,11 \%$ & $4,04 \%$ & 1 \\
\hline US & $35,40 \%$ & $1,40 \%$ & $37,52 \%$ & $32,70 \%$ & $4,82 \%$ & 2 \\
\hline India & $45,06 \%$ & $2,24 \%$ & $50,57 \%$ & $42,27 \%$ & $8,30 \%$ & 3 \\
\hline Brazil & $55,18 \%$ & $11,12 \%$ & $76,31 \%$ & $44,22 \%$ & $32,09 \%$ & 4 \\
\hline Canada & $55,26 \%$ & $2,02 \%$ & $58,18 \%$ & $51,64 \%$ & $6,54 \%$ & 5 \\
\hline Argentina & $56,89 \%$ & $2,34 \%$ & $60,98 \%$ & $53,92 \%$ & $7,06 \%$ & 6 \\
\hline Korea & $57,73 \%$ & $6,50 \%$ & $67,61 \%$ & $48,13 \%$ & $19,48 \%$ & 7 \\
\hline Japan & $58,25 \%$ & $2,58 \%$ & $64,25 \%$ & $54,17 \%$ & $10,08 \%$ & 8 \\
\hline Indenosia & $58,67 \%$ & $1,41 \%$ & $61,14 \%$ & $55,14 \%$ & $6,00 \%$ & 9 \\
\hline Mexico & $62,92 \%$ & $4,10 \%$ & $68,95 \%$ & $54,92 \%$ & $14,03 \%$ & 10 \\
\hline South Africa & $65,03 \%$ & $2,05 \%$ & $70,64 \%$ & $63,00 \%$ & $7,64 \%$ & 11 \\
\hline France & $67,17 \%$ & $1,78 \%$ & $70,67 \%$ & $63,68 \%$ & $6,99 \%$ & 12 \\
\hline Australia & $67,39 \%$ & $1,57 \%$ & $70,54 \%$ & $65,14 \%$ & $5,40 \%$ & 13 \\
\hline Russia & $70,85 \%$ & $6,92 \%$ & $80,16 \%$ & $52,08 \%$ & $28,08 \%$ & 14 \\
\hline Germany & $72,43 \%$ & $2,17 \%$ & $76,35 \%$ & $67,66 \%$ & $8,69 \%$ & 15 \\
\hline Poland & $78,01 \%$ & $3,00 \%$ & $83,81 \%$ & $73,46 \%$ & $10,35 \%$ & 16 \\
\hline Turkey & $78,75 \%$ & $2,80 \%$ & $83,68 \%$ & $72,29 \%$ & $11,39 \%$ & 17 \\
\hline Sweden & $79,66 \%$ & $2,56 \%$ & $83,43 \%$ & $73,45 \%$ & $9,98 \%$ & 18 \\
\hline Netherlands & $80,49 \%$ & $3,01 \%$ & $85,92 \%$ & $76,34 \%$ & $9,58 \%$ & 19 \\
\hline Belgium & $81,78 \%$ & $2,52 \%$ & $86,80 \%$ & $76,22 \%$ & $10,58 \%$ & 20 \\
\hline UK & $82,83 \%$ & $3,00 \%$ & $88,13 \%$ & $77,99 \%$ & $10,14 \%$ & 21 \\
\hline Spain & $84,03 \%$ & $3,09 \%$ & $89,45 \%$ & $76,52 \%$ & $12,93 \%$ & 22 \\
\hline Italy & $84,27 \%$ & $3,19 \%$ & $88,95 \%$ & $76,13 \%$ & $12,82 \%$ & 23 \\
\hline Venezuella & $84,87 \%$ & $4,74 \%$ & $95,42 \%$ & $78,90 \%$ & $16,52 \%$ & 24 \\
\hline Thailand & $86,99 \%$ & $1,28 \%$ & $89,72 \%$ & $84,64 \%$ & $5,08 \%$ & 25 \\
\hline Finland & $90,04 \%$ & $1,89 \%$ & $93,36 \%$ & $87,49 \%$ & $5,87 \%$ & 26 \\
\hline Iran & $91,23 \%$ & $2,55 \%$ & $97,34 \%$ & $88,38 \%$ & $8,96 \%$ & 27 \\
\hline Austria & $92,14 \%$ & $3,26 \%$ & $96,58 \%$ & $83,73 \%$ & $12,85 \%$ & 28 \\
\hline Chile & $93,51 \%$ & $6,47 \%$ & $100,00 \%$ & $83,94 \%$ & $16,06 \%$ & 29 \\
\hline Greece & $97,81 \%$ & $2,83 \%$ & $100,00 \%$ & $91,53 \%$ & $8,47 \%$ & 30 \\
\hline Norway & $97,96 \%$ & $3,07 \%$ & $100,00 \%$ & $90,09 \%$ & $9,91 \%$ & 31 \\
\hline Portugal & $98,79 \%$ & $2,01 \%$ & $100,00 \%$ & $91,32 \%$ & $8,68 \%$ & 32 \\
\hline Saudi Arabia & $98,88 \%$ & $1,47 \%$ & $100,00 \%$ & $94,77 \%$ & $5,23 \%$ & 33 \\
\hline Malaysia & $98,96 \%$ & $1,23 \%$ & $100,00 \%$ & $95,84 \%$ & $4,16 \%$ & 34 \\
\hline Romania & $99,01 \%$ & $1,51 \%$ & $100,00 \%$ & $94,32 \%$ & $5,68 \%$ & 35 \\
\hline Hungary & $99,18 \%$ & $1,40 \%$ & $100,00 \%$ & $95,74 \%$ & $4,26 \%$ & 36 \\
\hline Ukrania & $99,53 \%$ & $1,58 \%$ & $100,00 \%$ & $92,74 \%$ & $7,26 \%$ & 37 \\
\hline Peru & $99,65 \%$ & $0,70 \%$ & $100,00 \%$ & $97,53 \%$ & $2,47 \%$ & 38 \\
\hline Vietnam & $99,79 \%$ & $0,42 \%$ & $100,00 \%$ & $98,77 \%$ & $1,23 \%$ & 39 \\
\hline New Zealand & $99,86 \%$ & $0,46 \%$ & $100,00 \%$ & $97,93 \%$ & $2,07 \%$ & 40 \\
\hline Czech & $99,92 \%$ & $0,32 \%$ & $100,00 \%$ & $98,50 \%$ & $1,50 \%$ & 41 \\
\hline Bulgaria & $99,95 \%$ & $0,24 \%$ & $100,00 \%$ & $98,89 \%$ & $1,11 \%$ & 42 \\
\hline Israel & $99,97 \%$ & $0,13 \%$ & $100,00 \%$ & $99,37 \%$ & $0,63 \%$ & 43 \\
\hline Kazakhstan & $99,98 \%$ & $0,09 \%$ & $100,00 \%$ & $99,57 \%$ & $0,43 \%$ & 44 \\
\hline Denmark & $99,99 \%$ & $0,06 \%$ & $100,00 \%$ & $99,71 \%$ & $0,29 \%$ & 45 \\
\hline Ireland & $100,00 \%$ & $0,00 \%$ & $100,00 \%$ & $100,00 \%$ & $0,00 \%$ & 48 \\
\hline Morocco & $100,00 \%$ & $0,00 \%$ & $100,00 \%$ & $100,00 \%$ & $0,00 \%$ & 48 \\
\hline Philippines & $100,00 \%$ & $0,00 \%$ & $100,00 \%$ & $100,00 \%$ & $0,00 \%$ & 48 \\
\hline Egypt & $100,00 \%$ & $0,00 \%$ & $100,00 \%$ & $100,00 \%$ & $0,00 \%$ & 48 \\
\hline Pakistan & $100,00 \%$ & $0,00 \%$ & $100,00 \%$ & $100,00 \%$ & $0,00 \%$ & 48 \\
\hline
\end{tabular}


The ten worst environmental / greenhouse gas emissions performers from these 50 countries, are the following respectively (with respect to mean): China, USA, India, Brazil, Canada, Argentina, Korea, Japan, Indenosia and Mexico.

Five countries were found efficient throughout the period. These are: Ireland, Morocco, Philippines, Egypt, and Pakistan.

The boxplot graph which gives us a plenty information about performance scores of the countries which are minimum, maximum, approximate value of mean (median), distribution of 25 percent slices, variability, homogeneity and skewness of data is in the below.

According to Graph 4, the countries with the two worst performance scores belong to China and USA.

The two highest variability in performance scores belong to Australia and Brazil. 
Graph 4: Boxplot of Performance Skores of $\mathbf{5 0}$ Countries

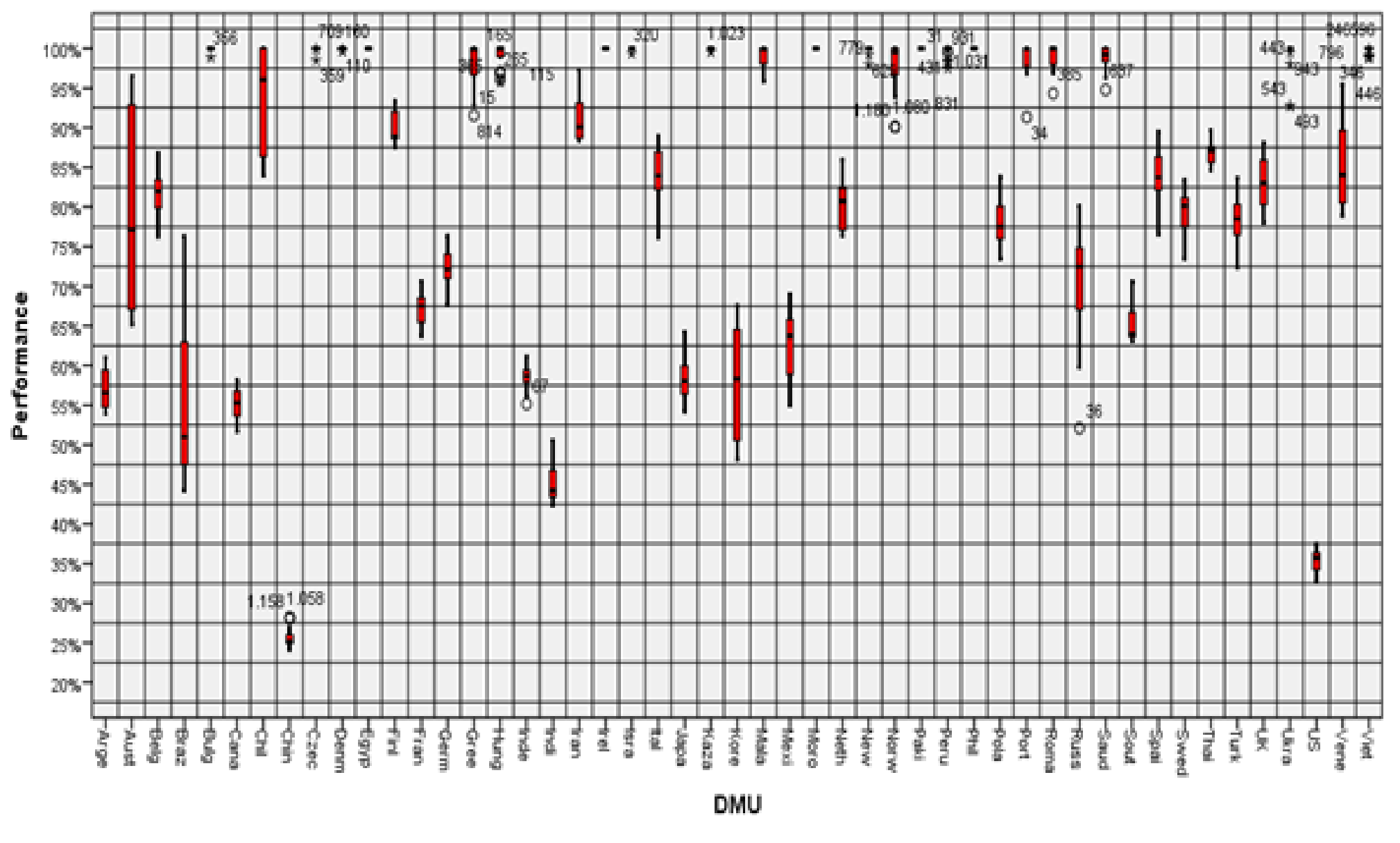


Stability and trend of EE scores of efficient countries ( Ireland, Morocco, Philippines, Egypt, and Pakistan land Turkey in the following Graph 5. The situation of the efficient countries is most desirable. In the study, ten years time period was taken into consideration. In the WA application, two performance scores were calculated for each year - with a logic of moving averages in the time series analysis- and an extra performance score for the last year. Thus, 21 performance scores were obtained for each DMU.

Graph 5:Stability And Trend of EE Scores of Efficient Countries and Turkey

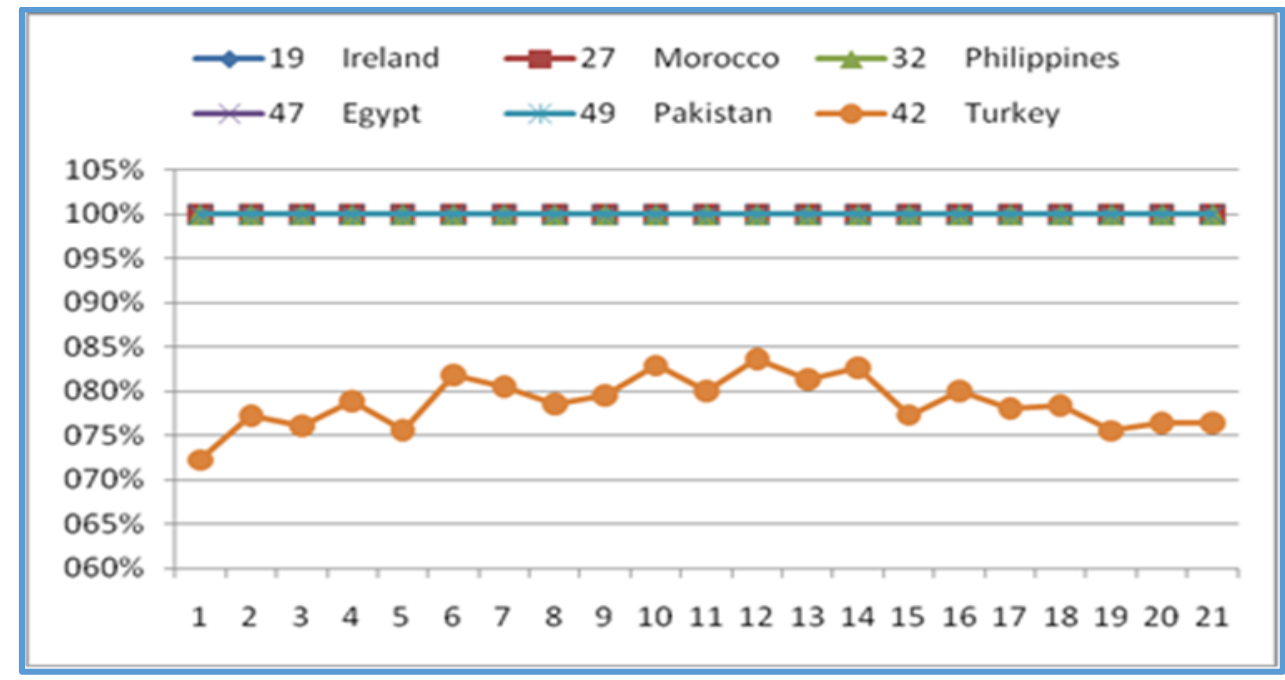

Stability and trend of EE scores of worst 10 coutries ( China, USA, India, Brazil, Canada, Argentina, Korea, Japan, Indenosia and Mexico) and Turkey in the following Graph 6.

Graph 6:Stability and Trend of EE Scores of Worst 10 Countries and Turkey

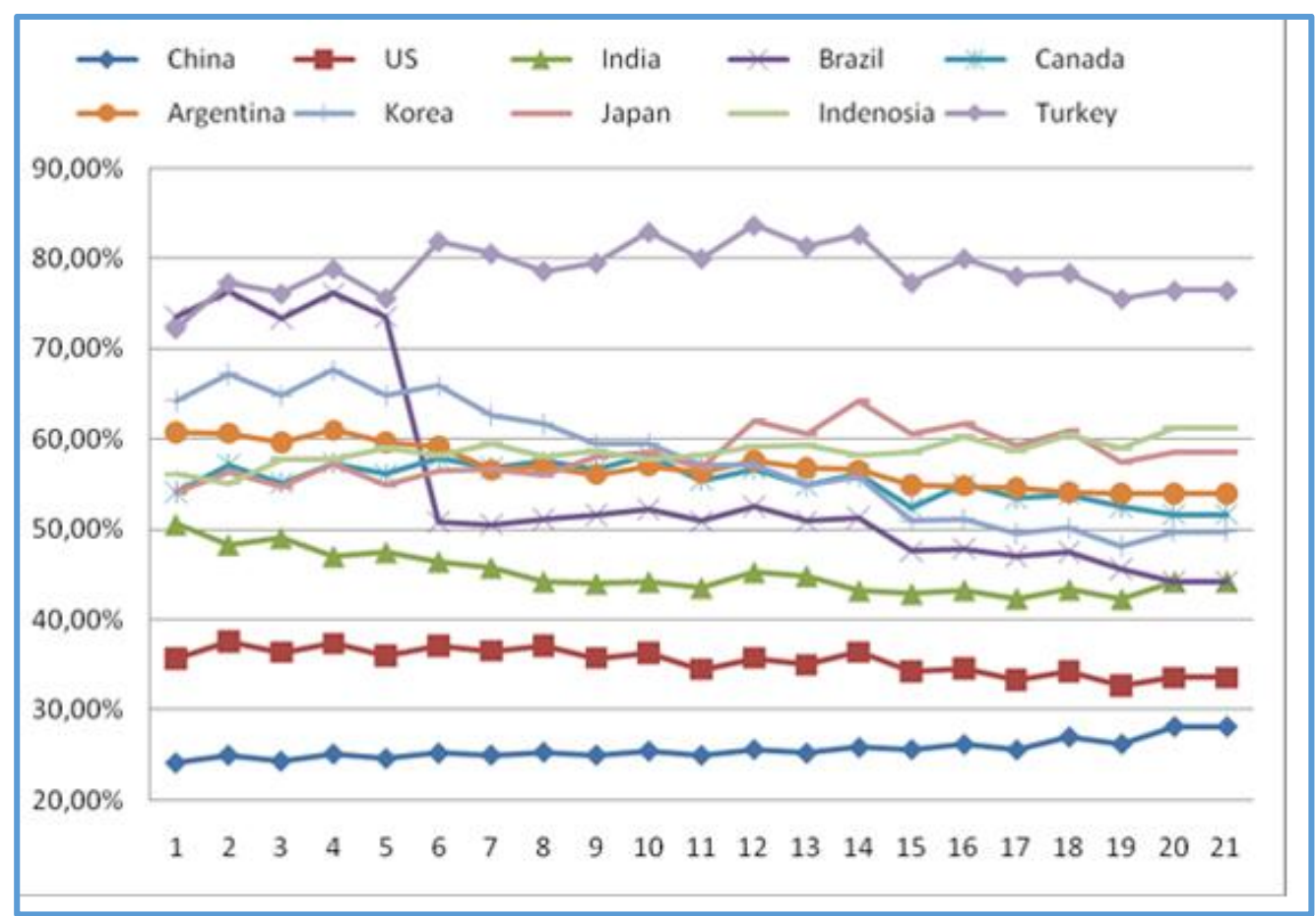

Stability and trend of EE scores of Brazil and Argentina in the following Graph 7. 
Graph 7:Stability and Trend of Brazil and Argentina

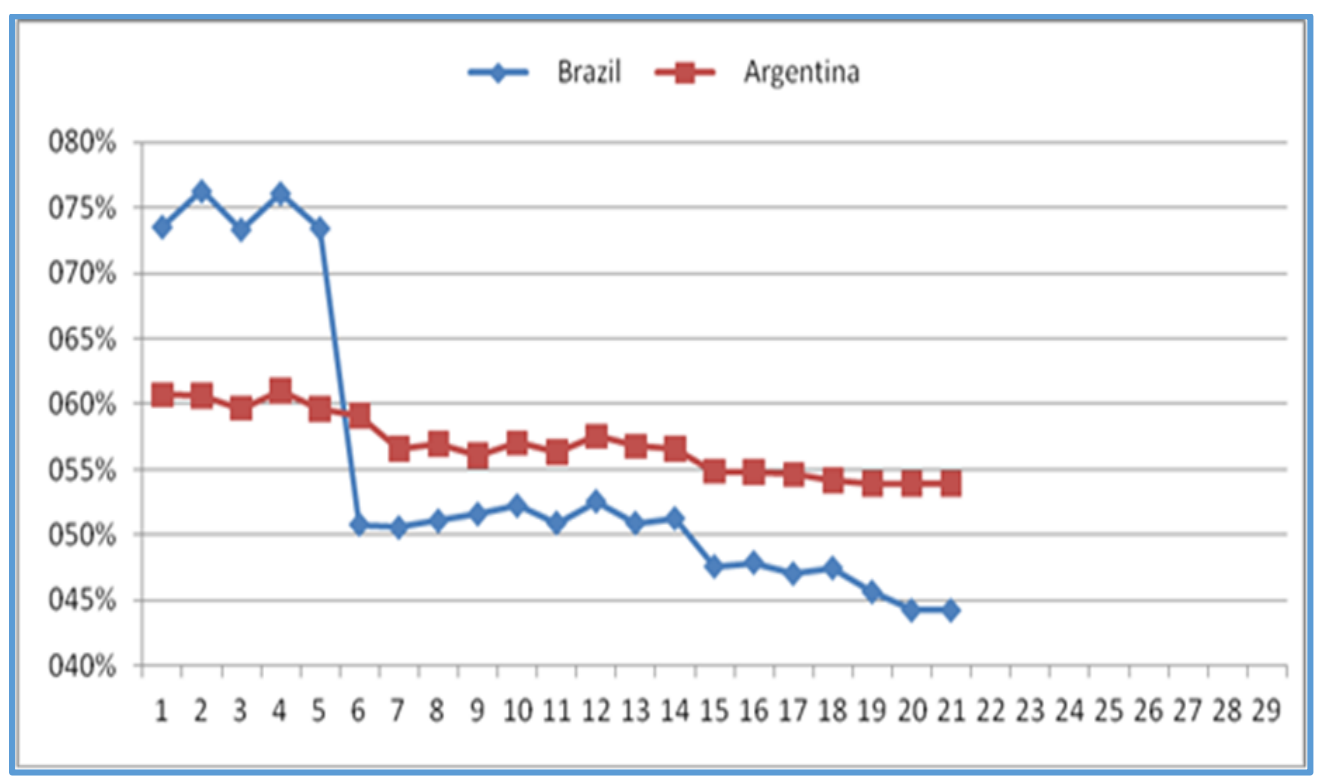

Rapid and major changes, as well as the decline in the environmental performance trends of countries, are considered absolutely negative. As can be seen in Graph 7, Brazil's environmental performance score showed a significant decline over a certain period of time. The reason of this is that, in that time zone, forest fires and land use for agriculture. This is also a reason for the variation which is quite high in Brazil's environmental performance scores (standard deviation and range, $11,12 \%, 32,09 \%$ respectively). And also Argentina has a continuously decreasing environmental performance trend.

\section{Conclusion and Discussion}

Apart from a few countries (Australia, Brazil, etc.) there is so much change in the EE performance of the countries. Wide range of dispersion, sudden alterations and steadily decreasing trend are undesirable for efficient countries throughout the process. Countries with the widest range of change are: Brazil, Russia, Korea, Venezuella and Mexico.

The five worst environmental performers with respect to mean from these 50 countries are the followings: China, USA, India, Brazil and Canada (25,59\%, 35,40\%, 45,06\%, 55,18\%, 55,26\%) respectively.

The ranking of five countries with the best environmental efficiency performance over the years studied is as follows: Ireland, Morocco, Philippines, Egypt and Pakistan with score $100 \%$.

Turkey's ranking among these countries is 34 and values are as follows: Mean=78.75, Standart deviation=2.8, Max=83.68, Min=72.29 and Range=11.39. The aggregate average statistics of the other countries considered in the study are as follows: $82,58 \%, 19,56 \%, 24,11 \%, 100,00 \%, 75,89 \%$ respectively.

Turkey should focus on renewable energy sources that will reduce the solid fuels it uses to increase its EE performance. To this end, in 2017, Turkey has been committed to increasing wind energy investments to a record level. Moreover, the institution of nuclear and new hydroelectric power plants is on the agenda of Turkey.

The average performance of the fifty countries between 2005 and 2015 was $82.63 \%$. This result suggests that for a better world these countries should reduce greenhouse emissions by mean $17.37 \%$. 


\section{References}

Agrell, P.J. and Bogetoft, P. (2005). Economic and Environmental Efficiency of District Heating Plants, Energy Policy, 33(10), 1351-1362.

Aigner, D., Lovell, C.K. and Schmidt, P. (1977). Formulation ond Estimation of Stochastic Frontier Production Function Models, J Econ, 6 (1), 21-37.

Alp, ì. and Sözen A.(2011). Efficiency Assessment of Turkey's Carbonization Index, Energy Sources, Part A: Recovery, Utilization, and Environmental Effects,33(18), 1678-1691.

Chang, Y.-T., Zhang, N., Danao, D. and Zhang, N. (2013). Environmental Efficiency Analysis of Transportation System in China: A Non-Radial DEA Approach, Energy Policy, 58, 277-283.

Charnes, A., Cooper, W.W. and Rhodes, E. (1978).Measuring the Efficiency of Decision Making Units, European Journal of Operational Research, 2 (6), 429-444.

Chien, T. and Hu, J.L. (2007). Renewable Energy and Macroeconomic Efficiency of OECD and NonOECD Economies, Energy Policy, 35 (7), 3606-3615.

Cook, W.D. and Seiford, L. M. (2009). Data Envelopment Analysis (DEA) - Thirty Years on, European Journal of Operational Research, 192, 1-17.

Cooper, W.W., Seiford, L.M. and Zhou, J. (2006). Handbook on Data Envelopment Analysis. Boston: Kluwer Academic Publishers, 24.

Demirbas, A. (2003). Energy and Environmental Issues Relating to Greenhouse Gas Emissions in Turkey, Energy Conversion and Management, 44, 203-213.

Emrouznejad, A., Parker, B. R. and Tavares, G. (2008). Evaluation of Research in Efficiency and Productivity: A Survey and Analysis of the First 30 Years of Scholarly Literature in DEA, Socio-Economic Planning Sciences, 42(3), 151-157.

Farrell, M. J. (1957). The Measurement of Productive Efficiency, Journal of the Royal Statistical Society. Series A (General), 120(3), 253-290.

Halkos, G.E. and Tzeremes, N.G. (2013). A Conditional Directional Distance Function Approach for Measuring Regional Environmental Efficiency: Evidence from UK Regions, European Journal of Operational Research, 227 (1), 182-189.

Honma, S. and Hu, J. (2009) .Total-Factor Energy Productivity Growth of Regions in Japan, Energy Policy, 4,34.

Honma, S. and Hu, J. (2008). Total-Factor Energy Efficiency of Regions in Japan, Energy Policy, 36, 821-833.

Lee, T., Yeo, G.T. and Thai, V.V. (2014). Environmental Efficiency Analysis of Port Cities: SlacksBased Measure Data Envelopment Analysis Approach, Transport Policy, 33, 82-88.

Li X.-G., Yang J. and Liu X.-J. (2013). Analysis of Beijing's Environmental Efficiency and Related Factors Using a DEA Model that Considers Undesirable Outputs, Math Comput Model, 58 (5), 956-960.

Lozano, S. and Gutierrez, E. (2008). Non-Parametric Frontier Approach to Modeling Therelationships among Population, GDP, Energy Consumption and CO2 Emissions, Ecological Economics 66, 687-699.

Mandal, K. and Madheswaran, S. (2010). Environmental Efficiency of the Indian Cement Industry: an Interstate Analysis, Energy Policy, 38(2), 1108-1118.

Meeusen, W. and Broeck, J. V.D. (1977). Efficiency Estimation from Cobb-Douglas Production Functions with Composed Error, Int Econ Rev, 435-444. 
Ramakrishnan, R. (2006). A Multi-Factor Efficiency Perspective to the Relationships Among World GDP, Energy Consumption aand Carbon Dioxide Emissions. Technological Forecasting \& Social Change, 73, 483-494.

Ray, S.C. (2004). Data Envelopment Analysis: Theory and Techniques for Economics and Operations Research, UK: Cambridge University Pres.

Reinhard, S., Lovell, C.A.K. and Thijssen, G.J. (2000). Environmental Efficiency with Multiple Environmentally Detrimental Variables; Estimated with SFA and DEA, European Journal of Operational Research, 121(2), 287-303.

Song, M. and Guan, Y. (2014). The Environmental Efficiency of Wanjiang Demonstration Area: A Bayesian Estimation Approach, Ecol Indic, 36, 59-67.

Song, M., Song, Y., An, Q. and Yu, H. (2013). Review of Environmental Efficiency and its Influencing Factors in China: 1998-2009, Renewable and Sustainable Energy Reviews, 20, 8-14.

Sözen, A. and Alp, i. (2009). Comparison of Turkey's Performance of Greenhouse Gas Emissions and Local/Regional Pollutants with EU Countries, Energy Policy, 37,5007-5018.

Tunc, G.I., Aşık, S.T. and Akbostancı, E. (2007). CO2 Emissions Vs. CO2 Responsibility: An InputOutput Approach for the Turkish Economy, Energy Policy, 35, 855-868.

Wang, H., Zhou, P. and Zhou, D. (2013). Scenario-Based Energy Efficiency and Productivity in China: A Non-Radial Directional Distance Function Analysis, Energy Econ, 40, 795-803.

Wang, K., Yu, S. and Zhang, W. (2013). China's Regional Energy and Environmental Efficiency: A DEA Window Analysis Based Dynamic Evaluation, Math Comput Model, 58 (5), 1117-1127.

Woo, C., Chung, Y., Chun, D., Seo, H. and Hong, S. (2015). The Static and Dynamic Environmental Efficiency of Renewable Energy: A Malmquist Index Analysis of OECD Countries, Renew Sustain Energy Rev, 47, 367-376.

U.S. Environmental Protection Agency (2017). Retrieved from https://www.epa.gov/ghgemissions/global-greenhouse-gas-emissions-data references 12-3.

Yang, L. and Wang, K.-L.(2013).Regional Differences of Environmental Efficiency of China's Energy Utilization and Environmental Regulation Cost Based on Provincial Panel Data and DEA Method, Math Comput Model, 58 (5), 1074-1083.

Zhou, P., Poh, K.L. and Ang, B.W., (2007). A Non-Radial DEA Approach to Measuring Environmental Performance, European Journal of Operational Research, 178 (1), 1-9.

Zhou, Y., Xing, X., Fang, K., Liang, D. and Xu, C. (2013). Environmental Efficiency Analysis of Power Industry in China Based on an Entropy SBM Model, Energy Policy, 57,68-75.

Zhou, Y., Liang, D. and Xing, X. (2013). Environmental Efficiency of Industrial Sectors in China: An Improved Weighted SBM Model, Math Comput Model, 58(5),990-9.

Zofio, J.L. and Prieto, A.M. (2001). Environmental Efficiency and Regulatory Standards: The Case of CO2 Emissions from OECD Industries, Resource and Energy Economics, 23(1), 63-83. 
